\title{
Transfer and Metabolism of Retinol by the Perfused Human Placenta
}

\author{
JOSEPH DANCIS, MORTIMER LEVITZ, JOSEPH KATZ, DAVID WILSON, WILLIAM S. BLANER, \\ ROSEANN PIANTEDOSI, AND DEWITT S. GOODMAN ${ }^{1}$ \\ Department of Pediatrics [J.D., D.W.] and Department of Obstetrics and Gynecology [M.L., J.K.], New York \\ University Medical Center and the Institute of Human Nutrition, Columbia University College of Physicians and \\ Surgeons [W.S.B., R.P., D.S.G.], New York, New York 10016
}

\begin{abstract}
The transfer and metabolism of retinol by human placenta was investigated using an in vitro perfusion system with independent maternal and fetal circulations. ${ }^{3} \mathrm{H}$-retinol bound to albumin added to the maternal perfusate was rapidly taken up and concentrated by the placenta to levels $16.5 \pm 5.28$ times the maternal perfusate. Approximately $8 \%$ of the retinol retained in the placenta was esterified. No metabolites were detected in the perfusates. Perfusion of placenta with retinol bound to retinol-binding protein (RBP) reduced the placental concentration to 4.4 \pm 1.72 times the maternal concentration and eliminated evidence of metabolism. The transfer rate of RBP: ${ }^{3} \mathrm{H}-$ retinol was less than that of albumin: ${ }^{14} \mathrm{C}$-retinol when measured concurrently in three experiments (clearances 0.11 versus $0.75 \mathrm{~mL} / \mathrm{min}, 0.21$ versus $1.7 \mathrm{~mL} / \mathrm{min}$, and 0.29 versus $0.48 \mathrm{~mL} / \mathrm{min}$, respectively). Transfer of the radioactive retinol was more rapid than ${ }^{125}$ I-RBP or albumin, indicating that retinol was transferred independently of the proteins. The transfer index of retinol (clearance retinol:clearance $L$-glucose) was $0.73 \pm 0.085$ compared to 2.1 \pm 0.36 for thiamin and $3.4 \pm 0.95$ for riboflavin, both water-soluble vitamins with active transport systems. The retinol transferred to the fetal perfusate is not bound to RBP, as demonstrated by gel filtration chromatography and chromatography on a transthyretin affinity column, despite the availability of RBP in the cord serum added to the perfusate. The endogenous retinol in the cord serum is bound to RBP. The conclusions derived are that RBP binding reduces the accumulation of retinol in the placenta and the transfer to the fetus, that retinol is transferred intact to the fetal circulation where immediate binding is not to RBP, and that redistribution to RBP occurs subsequently, possibly in fetal liver. (Pediatr Res 32: 195-199, 1992)
\end{abstract}

\section{Abbreviations}

\section{RBP, retinol-binding protein}

TTR, transthyretin

RBP:retinol, retinol bound to retinol-binding protein albumin:retinol, retinol bound to albumin

TCA, trichloroacetic acid

Received January 2, 1992; accepted March 20, 1992.

Correspondence and reprint requests: Joseph Dancis, M.D., New York University Medical Center, 550 First Ave., TH 528, New York, NY 10016.

Supported by grants from the Langer Foundation and the NIH (DKO5968, DK43097).

Deceased.
The importance of vitamin A to the developing mammalian fetus has been amply demonstrated in the experimental animal. Both deficiencies and excesses are teratogenic $(1,2)$. The pertinence of these observations to the human has recently become tragically evident. Retinoic acid administered to the pregnant female for the treatment of acne has caused severe congenital abnormalities in the newborn infant (3).

Despite its obvious importance, little is known about the placental transfer of retinoids. The question has been approached in the sheep (4) and monkey (5), but the placental role is difficult to deduce from studies in the intact animal and extrapolation of results to the human is uncertain. Measurements have been made in the human of maternal and cord retinol levels (6) that are interesting but shed little light on placental functions. Torma and Vahlquist (7) have studied the uptake of vitamin A and RBP by fragments of human placenta in vitro and speculated concerning the transplacental process. The model, however, does not permit differentiation of events at the maternal surface of the placenta from those at the fetal surface.

In the present study, we have used the technique of in vitro perfusion of a human placental lobule. By establishing independent "maternal" and "fetal" circulations, it was possible to study the transplacental transfer of retinol, the principal circulating form of vitamin A. In vitro, retinol circulates bound to a specific serum protein, RBP, which in turn complexes with TTR $(8,9)$. We have investigated the placental transfer and metabolism of retinol bound to RBP and compared the results to retinol bound nonspecifically to serum albumin. The comparison has provided insights into the physiologic role of RBP and the biochemical mechanism through which retinol is taken up by the tissues.

\section{MATERIALS AND METHODS}

Perfusion technique. Term placentas of clinically normal pregnancies were obtained after delivery by cesarean section or by vagina. Independent maternal and fetal circulations were established to a placental lobule as previously described (10). Flow rates approximated $12-15 \mathrm{~mL} / \mathrm{min}$ on the maternal side and 4$6 \mathrm{~mL} / \mathrm{min}$ on the fetal side. In the "closed" experiments, the perfusate was recirculated through a $70-\mathrm{mL}$ reservoir. The perfusions were performed under reduced lighting, as were all procedures with retinol, because of its light sensitivity.

Perfusate. The basic perfusate consisted of Earle's buffered salt solution equilibrated against $\mathrm{O}_{2}-\mathrm{CO}_{2}, 95-5 \%$, pH 7.4, with 150 $\mathrm{mg} / \mathrm{dL}$ of $\mathrm{D}$-glucose and mixed amino acids in physiologic concentration. In the experiments with albumin-bound retinol, 10 $\mathrm{g} / \mathrm{L}$ BSA was added to the perfusate with ${ }^{3} \mathrm{H}$-retinol $\sim 20000$ $\mathrm{cpm} / \mathrm{mL}$ and retinol $1.7 \mu \mathrm{mol} / \mathrm{L}$. Ten $\mathrm{g} / \mathrm{L}$ albumin in the perfusate solubilizes the retinol and provides sufficient binding to prevent absorption to the perfusion tubing and apparatus similar to previous experience with vitamin D (11). Binding was accomplished by incubating ${ }^{3} \mathrm{H}$-retinol with BSA for $1 \mathrm{~h}$. For the $\mathrm{RBP}$ experiments, ${ }^{3} \mathrm{H}$-retinol was bound to RBP by incubation 
at $37^{\circ} \mathrm{C}$ for $1 \mathrm{~h}$ or at $5^{\circ} \mathrm{C}$ overnight, while rotating gently. The RBP:retinol was added to perfusate containing $20 \%$ maternal serum.

Preparation of samples for analysis. Perfusate samples were added directly to scintillant to determine radioactivity. If there was an insufficient concentration of counts for chromatographic analysis, samples were first concentrated with an Amicon-B15 concentrator (Amicon Corp., Beverly, MA) for gel filtration analysis or by extraction with hexane for reverse phase chromatography. Throughout the analytical procedures, retinol was protected against oxidation by the addition of butylated hydroxytoluene, $6.1 \mathrm{mM}(1 \mathrm{mg} / \mathrm{mL})$, or $\alpha$-tocopherol, $100 \mu \mathrm{g}$.

At the end of the perfusion, 2-4 g of villous tissue was dissected from the perfused placenta and homogenized in 10 volumes of methanol:hexane (1:9). The extraction was repeated and both extracts combined and evaporated under vacuum. The residue was dissolved in $3 \mathrm{~mL}$ hexane containing $6.1 \mathrm{mM}$ butylated hydroxytoluene, transferred to a small tube, and taken to dryness. The residue was dissolved in $0.5-1.0 \mathrm{~mL}$ of methanol and passed through a $0.22-\mu \mathrm{m}$ filter, and 100 to $500 \mu \mathrm{L}$ were analyzed by HPLC.

Chromatographic analysis. Reverse phase HPLC was used to identify retinoic acid, retinol, and the retinyl esters. Separation was on a Waters RPC-18 column (Waters Associates, Milford, MA) with a UV detector at $325 \mathrm{~nm}$. The mobile phase was $80 \%$ acetonitrile in $1 \%$ ammonium acetate with a flow rate of $1 \mathrm{~mL} /$ $\mathrm{min}$. Retinol and retinoic acid, $100 \mu \mathrm{g}$, were added to the sample before injection to serve as standards, the former eluting at 7 min and the latter at $4.5 \mathrm{~min}$. For the retinyl esters, $100 \%$ methanol was the mobile phase, retinyl palmitate was the standard, and elution time was $13.4 \mathrm{~min}$ (12).

High performance gel filtration was performed to separate materials according to molecular size (13). Samples were injected into a Waters TSK $2000 \mathrm{SW}$ column equipped with a UV or fluorescence detector. The mobile phase was $0.1 \mathrm{M}$ monobasic potassium phosphate titrated to $\mathrm{pH} 7.4$ and $0.05 \%$ sodium azide. Elution times were $14.4 \mathrm{~min}$ for albumin and $20.1 \mathrm{~min}$ for RBP.

A TTR-sepharose affinity column was used to identify RBPbound retinol. The column was equilibrated at room temperature in $50 \mathrm{mM}$ tris-chloride, $150 \mathrm{mM} \mathrm{NaCl}$, and $0.05 \% \mathrm{NaN}_{3}$ at $\mathrm{pH}$ 7.4. Samples were applied and recycled through a $2-\mathrm{mL}$ reservoir for $2 \mathrm{~h}$ at room temperature. The column was washed with 22 $\mathrm{mL}$ of buffer to remove materials not bound to the column and then the bound RBP was eluted with $30 \mathrm{~mL} \mathrm{H}_{2} \mathrm{O}$ at $\mathrm{pH} 8.0$. Under these conditions, approximately $50 \%$ of the RBP in the sample equilibrated with and was retained by the column.

Normal phase chromatography was carried out on two Waters $5 \mu \mathrm{m}$ Resolve Silica columns linked in series and eluted with $0.4 \%$ diethyl ether in hexane flowing at $1.2 \mathrm{~mL} / \mathrm{min}$, using a previously described procedure for the separation of the geometric isomers of retinol (14).

Clearances. Clearance $(\mathrm{mL} / \mathrm{min})$ was calculated as previously described (10).

Materials. Perfusates were prepared by GIBCO (Grand Island, NY) according to specifications. Retinol $[11,12(\mathrm{n})]^{3} \mathrm{H}$-vitamin A alcohol, $60 \mathrm{Ci} / \mu \mathrm{mol}$; inulin- ${ }^{14} \mathrm{C}$-carboxylic acid, $9 \mathrm{mCi} / \mu \mathrm{mol}$; and $\mathrm{L}-1-{ }^{14} \mathrm{C}$-glucose, $40-60 \mathrm{mCi} / \mu \mathrm{mol}$, were purchased from Amersham (Arlington Heights, IL). The retinoids were obtained from Sigma Chemical Co. (St. Louis, MO) and the HPLC solvents from Fisher Scientific Co. (Pittsburgh, PA). If indicated, the ${ }^{3} \mathrm{H}$-retinol was further purified by reverse-phase chromatography with $\alpha$-tocopherol as antioxidant.

RBP was purified to homogeneity from human serum by conventional chromatography as previously described (15). Human ${ }^{125}$ I-RBP was prepared by the lactoperoxidase method according to standard procedures (16). The TTR:sepharose affinity column was prepared by cross-linking $10 \mathrm{mg}$ of purified TTR (15) to $5 \mathrm{~mL}$ of $\mathrm{CNBr}$-activated sepharose 4B (LKB-Pharmacia Biochetechnology Inc., Piscataway, NJ) following the instructions provided by the manufacturer.

\section{RESULTS}

Transfer and Metabolism of Albumin-Bound Retinol. ${ }^{3} \mathrm{H}$-retinol was incubated with serum albumin at $37^{\circ} \mathrm{C}$ for $1 \mathrm{~h}$, which permitted protein-binding as demonstrated by TCA precipitation. The albumin-bound retinol was added to the maternal perfusate, which contained $10 \mathrm{~g} / \mathrm{L}$ serum albumin, and recirculated for the duration of the perfusion. The fetal perfusate, which also contained $10 \mathrm{~g} / \mathrm{L}$ serum albumin, was kept open (two experiments) or recirculated (four experiments).

Placental uptake. Uptake of ${ }^{3} \mathrm{H}$-retinol from the maternal perfusate was very rapid during the first $20 \mathrm{~min}$ and continued at a slower rate throughout the perfusion. At the end of the perfusion, the concentrations of ${ }^{3} \mathrm{H}$-retinol in the placenta and in the maternal perfusate were measured. The concentration in the placenta was $16.5 \pm 5.28$ times that in the perfusate (Table 1).

In five experiments, the albumin-bound ${ }^{3} \mathrm{H}$-retinol was added to the fetal perfusate that was recirculated. The ratio of the concentrations of ${ }^{3} \mathrm{H}$-retinol in the placenta to the fetal perfusate was $16.0 \pm 4.79$, suggesting that similar mechanisms were involved in uptake and concentration of retinol from the maternal and fetal perfusate.

Metabolism. The maternal and fetal perfusates were analyzed by reverse phase HPLC. No radioactive metabolites were detected. In four experiments, the placenta was extracted at the completion of the perfusion and also analyzed. Over $90 \%$ of the radioactivity coeluted with retinol; $8,4,7$, and $11 \%$ eluted with retinyl esters. Retinoic acid was not detected.

Placental transfer. Transplacental clearances of ${ }^{3} \mathrm{H}$-retinol were calculated (Table 2). ${ }^{14} \mathrm{C}$-inulin was included in these experiments to provide a simultaneous measure of diffusion of a large $(5-\mathrm{kD})$, water-soluble molecule. Retinol was transferred 10 -fold more rapidly than inulin $(10.2 \pm 2.58)$. Albumin, to which the retinol was bound, is larger than inulin $(60 \mathrm{kD})$, with a permeability constant across the perfused placenta of $1.5 \times 10^{-3} \mathrm{~cm}^{3} / \mathrm{min} / \mathrm{g}$ as compared to $6.0 \times 10^{-3} \mathrm{~cm}^{3} / \mathrm{min} / \mathrm{g}$ for inulin (17). It is evident that retinol had to be released from albumin before or during transport to permit its more rapid transfer.

Transfer and Metabolism of RBP-Bound Retinol. Transfer of $R B P$. Retinol circulates in maternal and fetal serum bound to RBP. The possibility that retinol was transferred to the fetus as RBP:retinol was initially addressed. RBP:retinol was iodinated with ${ }^{125} \mathrm{I}$ and added to the maternal perfusate with ${ }^{14} \mathrm{C}$-inulin. The maternal and fetal perfusates were recirculated for $120 \mathrm{~min}$ in two experiments.

Table 1. Uptake of maternal retinol by placenta*

\begin{tabular}{cccccc}
\hline & \multicolumn{2}{c}{ Albumin:retinol } & & \multicolumn{2}{c}{ RBP:retinol } \\
\cline { 5 - 6 } \cline { 5 - 6 } $\begin{array}{c}\text { Experiment } \\
\text { no. }\end{array}$ & $\begin{array}{c}\text { Duration of } \\
\text { perfusion } \\
(\mathrm{min})\end{array}$ & $\begin{array}{c}\text { Duration of } \\
\text { perfusion } \\
(\mathrm{min})\end{array}$ & {$[\mathrm{Pl}] /[\mathrm{M}] \dagger$} \\
\hline 1 & 100 & 18 & & 60 & 5.2 \\
2 & 60 & 17 & & 180 & 5.7 \\
3 & 120 & 24 & & 120 & 3.3 \\
4 & 120 & 14 & & 180 & 5.9 \\
5 & 100 & 8 & & 120 & 1.4 \\
6 & 120 & 18 & & 60 & 4.6 \\
Mean \pm SD & & $16.5 \pm 5.28$ & & $4.4 \pm 1.72$ \\
\hline
\end{tabular}

${ }^{*} \mathrm{H}$-retinol bound to albumin or to RBP was added to the maternal perfusate, which was recirculated. The fetal perfusate was kept open or closed without detectable effect on the placental concentration. At the completion of perfusion, the concentration of radioactive retinol in the placenta (counts $/ \mathrm{min} / \mathrm{g}$ ) was compared with that in the maternal perfusate (counts $/ \mathrm{min} / \mathrm{mL}$ ). The placenta removes and concentrates retinol more effectively when bound to albumin than when bound to RBP ( $p$ $<0.001)$.

$\dagger[\mathrm{Pl}] /[\mathrm{M}]=$ counts $/ \mathrm{min} / \mathrm{g}$ placenta:counts $/ \mathrm{min} / \mathrm{mL}$ maternal perfusate. 
Table 2. Transfer of albumin-bound retinol*

\begin{tabular}{ccc}
\hline $\begin{array}{c}\text { Experiment } \\
\text { no. }\end{array}$ & $\begin{array}{c}\text { Clearance } \\
(\mathrm{mL} / \mathrm{min})\end{array}$ & $\begin{array}{c}\text { Clearance ratio } \\
\text { (retinol:inulin) }\end{array}$ \\
\hline 1 & 0.30 & 15 \\
2 & 0.16 & \\
3 & $15.0 \dagger$ & 9 \\
4 & 0.15 & 8 \\
5 & 1.2 & 9 \\
6 & 0.37 & $10.2 \pm 0.32$ \\
\hline
\end{tabular}

* Albumin: ${ }^{3} \mathrm{H}$-retinol was added to the maternal perfusate with inulin${ }^{14} \mathrm{C}$. The maternal perfusate was recirculated through the placenta and transfer into the nonrecirculated fetal perfusate was measured. The transfer rate of retinol bound to albumin greatly exceeded that of inulin, a smaller molecule than albumin $(5$ vs $60 \mathrm{kD})$.

† This deviant value was excluded from the mean but not from the retinol:inulin ratios.

Periodic sampling of the fetal perfusate showed a linear increase in concentration of ${ }^{125} \mathrm{I}$ and ${ }^{14} \mathrm{C}$ throughout the perfusion. However, only $10 \%$ of the transferred ${ }^{125}$ I remained TCA precipitable, indicating extensive degradation of RBP during transfer. The maternal RBP remained over $90 \%$ TCA precipitable. Within the placenta, $55 \%$ of the ${ }^{125} \mathrm{I}$ was no longer TCA precipitable. It was evident that the placenta rapidly degraded the RBP and released the degradation products into the fetal circulation.

The rate of transfer of TCA-precipitable ${ }^{125} \mathrm{I}$ was 0.33 and 0.44 that of inulin in the two experiments. The extensive degradation of RBP during transfer across the placenta and the relatively slow rate of transfer made it very unlikely that retinol bound to RBP was transferred intact to the fetus. That possibility was further eliminated by later experiments described below.

Uptake of $R B P$. In the next series of experiments, ${ }^{3} \mathrm{H}$-retinol was incubated with purified RBP at $37^{\circ} \mathrm{C}$ for $1 \mathrm{~h}$. The RBP: ${ }^{3} \mathrm{H}-$ retinol was added to the maternal perfusate to which had been added maternal serum to a concentration of $20 \%$. Binding of ${ }^{3} \mathrm{H}$-retinol to RBP was confirmed by reverse-phase chromatography of the maternal perfusate before perfusion and after 40 min of perfusion. The fetal perfusate contained $20 \%$ cord serum.

The maternal perfusate was recirculated. The fetal perfusate was recirculated in three experiments and kept open in two.

At the completion of the perfusion, the concentration of ${ }^{3} \mathrm{H}-$ retinol in the placenta was much lower than in the experiments with albumin:retinol (Table 1).

Metabolism. No evidence of metabolism of the ${ }^{3} \mathrm{H}$-retinol was detected by reverse phase chromatography in the maternal and fetal perfusates or in placenta extracts. The retinyl esters observed with the high concentrations of retinol in the placenta after perfusion with albumin:retinol were not evident.

Placental transfer. The effect of RBP binding on the placental transfer of retinol was investigated by adding both RBP: ${ }^{3} \mathrm{H}-$ retinol and albumin: ${ }^{14} \mathrm{C}$-retinol to the maternal perfusate. Clearances of the two preparations were simultaneously measured in three experiments. RBP binding reduced the clearance of retinol as compared to albumin:retinol $(0.11$ versus $0.75 \mathrm{~mL} / \mathrm{min}, 0.21$ versus $1.7 \mathrm{~mL} / \mathrm{min}$, and 0.29 versus $0.48 \mathrm{~mL} / \mathrm{min}$ ).

It was interesting to compare the placental transfer rate of retinol to those of other nutrients studied with the same technique, particularly the water-soluble vitamins. For this information, RBP: ${ }^{3} \mathrm{H}$-retinol and $1{ }^{4} \mathrm{C}$-L-glucose were added to the maternal perfusate and the placental clearances simultaneously measured. L-Glucose is a water-soluble molecule transferred by membrane-limited simple diffusion. By using the ratio of the clearances of riboflavin to $\mathrm{L}$-glucose, interexperimental variation is reduced and comparison of substrates becomes more meaningful. The ratio of retinol to L-glucose clearance, or transfer index, in five experiments was $0.73 \pm 0.085$ (Table 3 ). The transfer indices of thiamin and riboflavin, two water-soluble
Table 3. Transfer rate of RBP-bound retinol

\begin{tabular}{ccc}
\hline Experiment no. & Clearance $(\mathrm{mL} / \mathrm{min})$ & Transfer index* \\
\hline 1 & 0.09 & 0.69 \\
2 & 0.34 & 0.81 \\
3 & $7.7 \dagger$ & 0.72 \\
4 & 0.11 & 0.82 \\
5 & 0.12 & 0.59 \\
Mean \pm SD & $0.37 \pm 0.32$ & $0.73 \pm 0.85$ \\
\hline
\end{tabular}

$*$ Transfer index $=$ clearance retinol:clearance L-glucose.

$\dagger$ Deviant value excluded from the mean but not from transfer index.

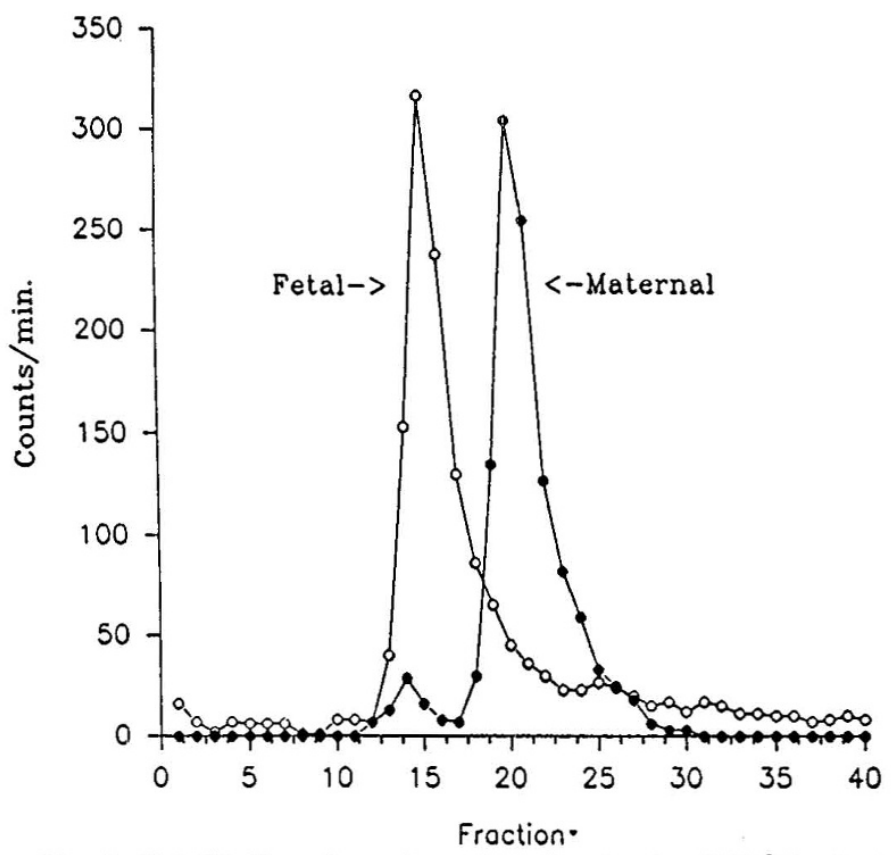

Fig. 1. Gel filtration chromatography of perfusates. RBP: ${ }^{3} \mathrm{H}-$ retinol was added to maternal perfusate with $20 \%$ serum and recirculated. Fetal perfusate, containing $20 \%$ cord serum, was not recirculated. After perfusing for $40 \mathrm{~min}$, the maternal and fetal perfusates were analyzed by HPLC gel filtration. Radioactivity in maternal perfusate eluted with $\mathrm{RBP}$; in fetal perfusate, with materials equal to or greater than $60 \mathrm{kD}$.

vitamins previously studied in this laboratory, were $2.1 \pm 0.36$ and $3.4 \pm 0.95$, respectively $(18,19)$

Protein-binding of transferred ${ }^{3} \mathrm{H}$-retinol. RBP: ${ }^{3} \mathrm{H}$-retinol was added to maternal perfusate containing $20 \%$ maternal serum and recirculated for $60 \mathrm{~min}$. The fetal perfusate containing $20 \%$ cord serum was not recirculated. After $40 \mathrm{~min}$, an aliquot of maternal perfusate was drawn from the reservoir and the fetal perfusate was collected. Both were analyzed by gel filtration on HPLC (Fig. 1).

With the maternal perfusate, a radioactive peak eluted at 21 min, consistent with RBP:retinol. In contrast, the radioactivity in the fetal perfusate eluted as a peak after $15 \mathrm{~min}$, consistent with molecules of $60 \mathrm{kD}$ and above.

The identity of the protein that binds the retinol was further pursued using a TTR affinity column that selectively binds to RBP. Under the conditions of analysis, approximately $50 \%$ of prepared $\mathrm{RBP}:{ }^{3} \mathrm{H}$-retinol is retained by the column. The maternal perfusate to which RBP: ${ }^{3} \mathrm{H}$-retinol had been added performed as would be expected (Table 4). The ${ }^{3} \mathrm{H}$-retinol in the fetal perfusate was not retained by the column, confirming that the transferred ${ }^{3} \mathrm{H}$-retinol was not bound to RBP.

The binding of the endogenous nonradioactive retinol contained in the sera added to the materrral and fetal perfusates was also investigated using the characteristic fluorescence of RBP:retinol. Retention by the affinity column was slightly higher than that of the laboratory-prepared RBP:retinol and was the 
Table 4. TTR column assay for RBP binding of retinol in maternal and fetal perfusate*

\begin{tabular}{cccccc}
\hline & \multicolumn{2}{c}{$\begin{array}{c}{ }^{3} \text { H-retinol } \\
\text { Experiment }\end{array}$} & & \multicolumn{2}{c}{$\begin{array}{c}\text { Endogenous retinol } \\
\text { (\% bound) }\end{array}$} \\
\cline { 2 - 3 } \cline { 5 - 6 } no. & Maternal & Fetal & & Maternal & Fetal \\
\hline 1 & 42 & $<10$ & & 69 & 78 \\
2 & 54 & $<10$ & & 74 & 73 \\
3 & 53 & $<10$ & & 61 & 74 \\
4 & 48 & $<10$ & & 49 & 72 \\
\hline
\end{tabular}

* RBP: ${ }^{3} \mathrm{H}$-retinol was added to the maternal perfusate containing $20 \%$ maternal serum and transfer into fetal perfusate with $20 \%$ cord serum was investigated. The affinity column retained about half the radioactivity in the maternal perfusate, similar to the results obtained with laboratory-prepared RBP:retinol. None of the transferred ${ }^{3} \mathrm{H}$-retinol was retained by the column. The endogenous retinol in the maternal and cord sera added to the perfusates was retained equally and at a slightly higher level than the laboratory-prepared maternal perfusate.

same in the maternal and fetal perfusates (Table 4), indicating that the endogenous retinol was bound to RBP in maternal and cord blood.

The difference in binding to the TTR-affinity column between the laboratory-prepared RBP:retinol and that circulating in serum (Table 4) may be explained by the method used for the laboratory preparation. Trace ${ }^{3} \mathrm{H}$-retinol was incubated with purified RBP, permitting binding to unoccupied sites on the protein and/or interchange with bound retinol. This technique was gentler than removing bound retinol with organic solvents and replacing it with ${ }^{3} \mathrm{H}$-retinol. Binding of ${ }^{3} \mathrm{H}$-retinol was demonstrated by TCA precipitation and gel filtration. Binding of tracer, however, may not have been identical to the endogenous retinol.

On reverse phase chromatography, the transferred radioactivity eluted with authentic retinol. The possibility remained that the transferred retinol had been subtly altered by metabolism, sufficient to interfere with RBP binding but not detectable by reverse phase chromatography. Normal phase chromatography provides greater resolution of the isomers of retinol and its metabolites. In two experiments, the transferred radioactivity eluted with authentic retinol. Direct evidence that the transferred ${ }^{3} \mathrm{H}$-retinol retained its capacity for RBP binding was obtained by extracting the transferred radioactivity from the fetal perfusate with hexane and incubating the extract with purified RBP at $37^{\circ} \mathrm{C}$ for $1 \mathrm{~h}$. There was complete binding of the extracted radioactivity. Therefore, the transferred ${ }^{3} \mathrm{H}$-retinol was unaltered and retained its potential for binding to RBP but had not bound to RBP even though the protein was present in the perfusate.

The possibility remained that the RBP circulating in fetal plasma was unable to accept the placentally transferred ${ }^{3} \mathrm{H}$ retinol because it was fully saturated. This was addressed by incubating cord serum with ${ }^{3} \mathrm{H}$-retinol. Reverse phase chromatography and TTR-affinity chromatography indicated that the ${ }^{3} \mathrm{H}$-retinol was bound to RBP.

\section{DISCUSSION}

Retinol is poorly soluble in water. Several carrier proteins have evolved for transporting retinol through aqueous environments. In the circulation, retinol is transported bound to a specific plasma protein, RBP (8). Cell surface receptors for RBP have been reported on the brush border of human placenta (20). The experiments with albumin-bound retinol demonstrate, however, that neither specific protein binding nor receptor-mediated transport are required for delivery of retinol to the placenta or the fetus.

The mechanisms involved in transport of albumin:retinol appear to be the same for other lipophilic materials when bound to albumin, as suggested by studies of the FFA and of estrogens $(21,22)$. The ligands are released from the protein to the placenta, bound to placental proteins, and then released to fetal albumin. Uptake and concentration of the ligand in the placenta are consistent with the relative association constants for albumin and placental proteins. The observations on transport can be explained physicochemically, but more complex biologic processes are not excluded.

Under physiologic conditions, retinol is delivered to the placenta bound to RBP. The first steps in transport of retinol to the fetus require release from RBP and uptake into the placenta. Noy and Blaner (23) have proposed a model for the cellular uptake of retinol that can be applied to the placenta. Retinol is progressively released from RBP in the circulation as it enters into equilibrium with the plasma membrane, where it moves from the outer leaflet to the inner leaflet of the membrane $(24$, 25 ). Retinol then interacts with cytoplasmic proteins. As with the albumin-bound hydrophobic materials, the concentration of retinol within the cell is determined by the relative binding affinities and available binding sites of the transport protein delivering the retinol and the intracellular binding proteins. Receptor-mediated transport (20) is not a feature of the model proposed by Noy and Blaner.

Placental uptake and transfer of ${ }^{3} \mathrm{H}$-retinol is reduced when ${ }^{3} \mathrm{H}$-retinol is bound to RBP as compared to albumin-bound retinol, consistent with the higher avidity of $\mathrm{RBP}$ for retinol and suggesting that the primary function of RBP is to control the delivery of retinol to tissues. RBP binding prevents excessive accumulation of a potentially harmful material. Vitamin D binding protein may have a similar function. The placental transfer of 25-hydroxycholecalciferol is sharply reduced when 25-hydroxycholecalciferol is bound to its specific transport protein as compared to transfer when bound to albumin (11).

There is no information concerning the route and mechanisms by which retinol traverses the placenta to reach the fetal circulation. The parallels between placental uptake of retinol and that of FFA suggest that similarities may exist in intracellular transport. A superfamily of structurally related intracellular proteins capable of binding lipophilic materials has been described (26). The members of this family include the fatty acid-binding proteins, cellular retinol-binding protein type I, cellular retinolbinding protein type II, cellular retinoic acid-binding protein, myelin P2, and adipocyte P2 (27). The proteins are located in the cytoplasm and are thought to play a role in the intracellular transport and metabolism of their respective hydrophobic ligands. The fatty acid-binding proteins that have been identified in human placenta appear to be unique isoforms, based on serologic evidence (28). At present, only limited information is available regarding the presence of retinoid-binding proteins in the human placenta. Cellular retinol-binding protein type I mRNA could not be detected by Northern blot analysis in total RNA from human placenta (29), but data concerning the possible presence of other retinoid-binding proteins in the placenta are not available.

The present studies have shown that retinol is transferred into the fetal circulation unchanged by placental metabolism and that the transferred retinol is not bound to RBP. On chromatography (Fig. 1), the transferred ${ }^{3} \mathrm{H}$-retinol is bound to protein(s) of 60 $\mathrm{kD}$ or greater. It is possible that the retinol is secreted bound to a placental protein. The placental synthesis of apolipoprotein E could provide such an opportunity (30). Alternatively, the retinol, on release from the placenta, binds immediately to available lipid carrier proteins such as albumin or lipoproteins. The fetal proteins, fetuin (31) and $\alpha$-fetoprotein (32), are also potential lipid carriers. This binding is transient, with subsequent transfer to RBP (Table 4) possibly accomplished in the liver.

\section{REFERENCES}

1. Wilson JG, Roth CB, Warkany J 1953 An analysis of the syndrome of malformation induced by maternal A deficiency. Effects of restoration of vitamin A at various times in gestation. Am J Anat 92:189-217

2. Cohlan SQ 1953 Excessive intake of vitamin A as a cause of congenital anomalies in the rat. Science 117:535-536 
3. Lammer EJ, Chen DT, Hoar RM, Agnish ND, Benke PJ, Braun JT, Curray CJ, Fernhoff PM, Grix Jr AW, Lott IT, Richard JM, Sun SC 1985 Retinoic acid embryopathy. N Engl J Med 313:837-841

4. Donoghue S, Richardson DW, Sklan D, Kronfeld DS 1982 Placental transport of retinol in sheep. J Nutr 112:2197-2203

5. Vahlquist A, Nilsson $S 1984$ Vitamin A transfer to the fetus and to the amniotic fluid in rhesus monkey (Macaca mulatta). Ann Nutr Metab 28:321-333

6. Jansson L, Nilsson B 1983 Serum retinol and retinol-binding protein in mothers and infants at delivery. Biol Neonate 43:269-271

7. Torma H, Vahlquist A 1986 Uptake of vitamin A and retinol-binding protein by human placenta in vitro. Placenta 7:295-305

8. Kanai M, Raz A, Goodman DS 1968 Retinol-binding protein: the transport protein for vitamin A in human plasma. J Clin Invest 47:2025-2044

9. Peterson PA 1971 Characteristics of a vitamin A-transporting protein complex occurring in human serum. J Biol Chem 246:34-43

10. Schneider H, Panigel M, Dancis J 1972 Transfer across the perfused human placenta of antipyrine, sodium and leucine. Am J Obstet Gynecol 114:822828

11. Ron M, Levitz M, Chuba J, Dancis J 1984 Transfer of 25-hydroxyvitamin $D^{3}$ and 1,25-dihydroxyvitamin $\mathrm{D}^{3}$ across the perfused human placenta. Am J Obstet Gynecol 148:370-374

12. Bhat PV, Lacroix A 1983 Separation and estimation of retinyl fatty acyl esters in tissues of normal rats by HPLC. J Chromatography 272:269-278

13. Futterman S, Heller J 1972 The enhancement of fluorescence and the decreased susceptibility to enzymatic oxidation of retinol complexed with bovine serum albumin, B-lactoglobulin and the retinol-binding protein of human plasma. J Biol Chem 247:5168-5172

14. Blaner WS, Das SR, Gouras P, Flood MT 1987 Hydrolysis of 11-cis and alltrans retinylplamitate by homogenates of human retinal epithelial cells. $\mathrm{J}$ Biol Chem 262:53-58

15. Blaner WS, Goodman DS 1990 Purification and properties of plasma retinolbinding protein. Methods Enzymol 189:193-206

16. Blaner WS 1990 Radioimmunoassays for retinol-binding protein, cellular retinol-binding protein, and cellular retinoic acid-binding protein. Methods Enzymol 189:270-281

17. Schneider H, Sodha RJ, Progler M, Young MPA 1985 Permeability of human placenta for hydrophilic substances studied in the isolated dually in vitro perfused lobe. In: Schneider H, Dancis J (eđs) Contributions to Gynecology and Obstetrics, Vol 13. Karger, Basel, Switzerland, pp 98-103

18. Dancis J, Lehanka J, Levitz M 1985 Transfer of riboflavin by perfused human placenta. Pediatr Res 19:1143-1146

19. Dancis J, Wilson D, Hoskins IA, Levitz M 1988 Placental transfer of thiamine in the human subject: in vitro perfusion studies and maternal-cord plasma concentrations. Am J Obstet Gynecol 159:1435-1439

20. Sivaprasadarao A, Findlay JBC 1988 The mechanism of uptake of retinol by plasma-membrane vesicles. Biochem $\mathbf{J}$ 255:571-579

21. Dancis J, Jansen V, Levitz M 1976 Transfer across perfused human placenta IV. Effect of protein-binding on free fatty acids. Pediatr Res 10:5-10

22. Dancis J, Jansen V, Levitz M 1980 Placental transfer of steroids: effect of binding to serum albumin and to placenta. Am J Physiol 238:E208-E213

23. Noy N, Blaner WS 1991 Interactions of retinol with binding proteins: studies with rat cellular retinol-binding protein and rat retinol-binding protein Biochemistry 30:6380-6386

24. Noy $\mathrm{N}, \mathrm{Xu} \mathrm{Z}$-J 1990 Kinetic parameters of the interactions of retinol with lipid bilayers. Biochemistry 29:3883-3888

25. Noy N, Xu Z-J 1990 Thermodynamic parameters of the binding of retinol to binding proteins and to membranes. Biochemistry 29:3888-3892

26. Ockner RK 1990 Historic overview of studies on fatty acid-binding proteins Mol Cell Biochem 98:3-9

27. Sweetser DS, Heuckeroth RO, Gordon JI 1987 The metabolic significance of mammalian fatty acid-binding proteins: abundant proteins in search of a function. Ann Rev Nutr 7:337-359

28. Veerkamp JH, Paulussen RJA, Peeters RA, Maatman RGHJ, van Moerkerk HTB, van Kuppevelt THMSM 1990 Detection, tissue distribution and (sub) cellular localization of fatty-acid-binding protein types. Mol Cell Biochem 98:11-18

29. Marks F, Piantedosi R, Blaner WS, Dancis J, Levitz M, Goodman DS 1991 Studies on the temporal and anatomic patterns of expression of retinolbinding protein (RBP), cellular retinol-binding protein (CRBP), and transthyretin (TTR) in human placenta. FASEB J 5:A717(abstr)

30. Rindler MJ, Traber MG, Esterman AL, Bersinger NA, Dancis J 1991 Synthesis and secretion of apolipoprotein $\mathrm{E}$ by human placenta and choriocarcinoma lines. Placenta 12:615-624

31. Kumbla L, Bhadra S, Subbiah MRT 1991 Mutlifunctional role for fetuin (fetal protein) In lipid transport. FASEB J 5:2971-2975

32. Parmelee DC, Evenson MA, Deutsch MJ 1978 The presence of fatty acids in human alpha-fetoprotein. J Biol Chem 253:2114-2119 